\title{
FAMILY BENEFITS IN MEMBER STATES OF THE EUROPEAN UNION: A COMPARATIVE PERSPECTIVE
}

\author{
Simona Maria STĂNESCU ${ }^{1}$, Mirela Ileana NEMȚANU ${ }^{2}$ \\ ${ }^{1}$ Research Institute for Ouality of Life, Romanian Academy \\ ${ }^{2}$ Romanian Academy of Economic Studies, Faculty of Marketing \\ (C) 2015 Simona Maria Stănescu, Mirela Ileana Nemțanu \\ This is an open access article distributed under the Creative Commons Attribution-NonCommercial-NoDerivs license \\ (http://creativecommons.org/licenses/by-nc-nd/3.0/)
}

DOI: 10.1515/eras-2015-0004

\begin{abstract}
The article intends to be a screening of family benefits in the 28 Member States of the European Union (EU) and to contribute to the research of shared trends with respect to family approach in these countries. Four types of family benefits including eight distinctive categories are analysed: child-benefit, child care allowances, childraising allowances, and other benefits (birth and adoption grants, allowance for single parents, special allowances for children with disabilities, advance payments for maintenance and other allowances). The paper is based on primary and secondary analysis of 28 sets of national data provided through the European Union's Mutual Information System on Social Protection (MISSOC). Three categories of member states are considered: founder member states of the EU, other "old" member states, and the new Central and Eastern ones. Chronological development of national regulations with impact on family benefits is analysed in connection with the moment of becoming a member state. Various forms of family benefits legislation and their main subjects of interest are further researched. The last part of the article looks at the coverage of family benefits. Seven member states operate in this respect based on regulations adopted before EU accession. Belgium, Finland, and Lithuania have the "most preserved" family regulations per category of member states. The first three topics of family regulations are: child, family, and allowance / benefit. The most frequently provided family benefits are: birth and adoption grants, and special allowance for children with disabilities. All eight family benefits are provided in France, Finland, Hungary, and Slovenia. Only two types of family benefits are available in Ireland, Spain, and Cyprus.
\end{abstract}

Keywords: family benefits, European Union, member states of the European Union, enlargement of the European Union

\section{Introduction}

In recent years, the public attention for families is supported by reconsidering its role alongside market and state in providing welfare in Post-Fordist societies (Esping-Andersen 1990; Leibfried 1993; Pierson 1996, Korpi, Palme 1998; Esping-Andersen, 1999; Koch 2006). Families are faced with a global context characterised by various "erosion" factors such as: demographic decline, decreasing marriages and births, increased number of divorces and new forms of families, late marriage age, lifestyle changes, improved access to long term education and vocational training, (Korpi, 2000, Popescu 2009, Mureșan 2014, 137-149). Children's care paradigm changes and new situations require integrative and suitable parent-education system approaches in tackling low school performance and even school drop-out and delinquent children (Pânzaru, Tomiță 2013, 21-36; Băluță 2014, 227-242; Tomita, 2014, 6785). Family relations have new dimensions: ethno-cultural particularities are shaping the conflicts among parents and children (Turliuc, Marici, 2013 42-46), school performance and adoption, 42-46, Băluță, 2014). Parents' needs in supporting child care could be resumed at: day care, and a friendlier working environment (Hirdman, 1994, p. 25) but both women and man tend to give priority to their career as an individual answer to transition from ,welfare to workfare".

The process of EU accession requires on-going adjustment of the acquis communautaire towards Europeanization of sovereign social protection systems and challenges of European 
Social Model (Vaughan-Whitehead, 2004; Vonica Radutiu 2004: Stănescu, 2006; Kvist, Saari, 2007; Stănescu, 2013). The configuration of family policies became a strategic element in answering to the weaker national capacity to support social costs. One of the late common tendencies among EU member states is the financial improvement of the family situation (European Commission, 2012, p. 4). The concern for better family policies is reflected by institutional settings and regulatory frameworks; leave policies, care services, and cash and tax benefits (Blum, S., Rille-Pfeiffer, C., 2010, pp. 6- 11). The more attention is paid to efficiently adjust family policies, the better are chances to increase fertility, to secure the work-life balance, and to protect children from social exclusion.

The paper assesses the current state of affairs in providing family benefits in Europe. In terms of methodology, the paper is based on primary and secondary analysis of 28 sets of national data provided through the European Union's Mutual Information System on Social Protection (MISSOC) on July 1st, 2014. Four categories of family benefits were identified: child-benefits, child-raising allowances, child care allowances and other benefits. Within this last category, five distinct types of allowances were analysed: birth and adoption grants, allowance for single parents, special allowances for children with disabilities, advance payments on maintenance and other allowances. Common definitions for the above mentioned categories of family benefits are not officially recognised at European level. Yet, the purpose for which these common actions are carried out, allow us to compare family benefits despite the lack of a common theoretical approach. By the time allotted in this respect, three categories of countries were identified: founder members of the EU; the following nine other "old" member states; and 13 Central and Eastern (CEE) new member states (the two steps 2004 Cyprus, Czech Republic, Estonia, Hungary, Latvia, Lithuania, Malta, Poland, Slovakia and Slovenia and 2007 Bulgaria and Romania of the fifth EU enlargement wave and the sixth 2013 wave represented by Croatia). Researched countries are enumerated in chronological order when referring to the EU accession time, and in alphabetic order when referring to the European overview and additionally by the three types of countries in the case of complementary in-depth analysis.

The first part looks at the chronological development of national regulations with impact on family benefits. The analysis of the historical socio-economic and cultural roots of the identified changes does not represent the topic of this part but it could be further researched. The second part looks at regulations of family benefits in connection with the moment of becoming a member state of the EU. The main question is if the current regulations in family benefits were adopted before or after accession to the EU. The assessment of the strengths and weaknesses in adopting the acquis communautaire is not included. The third part analyses in detail the various forms of legislation for family benefits among member states. The research of the main subjects of regulations in the field of family benefits offers a detailed picture on social policy common trends in approaching the family. The last part of the paper looks at the coverage of the identified eight categories of family benefits provided within the member states.

\section{Chronological development of regulations of family benefits}

One of the first questions analysing the subject of family benefits is to what extent these are flexible so as to adapt to current challenges? In other words, how frequent are their changes and since when is the last one in force? From this perspective, we looked both at the years when the latest legislative changes entered into force, and at the moment of joining the EU. The period starting with 1990 is more closely analysed due to the fall of the communist regimes from $\mathrm{CEE}$ and its impact on the social policy configuration. During the documentation phase, an unexpected additional reason supported this methodological option as the MISSOC database does not provide information on the applicable statutory basis before 1989 in the CEE member states.

Out of the applicable statutory basis, the oldest regulations with impact on family protection applicable today date back to 1939 (Belgium), 1955 (Italy), 1958 (Greece), and 1967 (Austria). The most recent ones date from 2014 (Bulgaria). Regular updates of the amounts for family benefits are noticed in all member states. Family related regulations adopted before '90s were chronologically noticed in Italy (1961, and 1988); in The Netherlands (1962); in 
Germany (1964, and 1979); in Belgium (1976); and in Greece (1980, 1983, 1984, and 1985). As of 1992, save for 1996, legislative changes were adopted yearly in both member states and candidate countries. Changes during the $90 \mathrm{~s}$ were registered in all three categories of countries: in one EU founder (Italy), in three other old member states (Finland, Spain, and United Kingdom), as well as in four Eastern member states (Bulgaria, Czech Republic, Hungary, and Romania). A more detailed picture is presented bellow:

- $\quad$ in 1992: Finland, and United Kingdom;

- $\quad$ in 1993: Romania;

- $\quad$ in 1994: Spain;

- $\quad$ in 1995: Czech Republic, and Hungary;

- $\quad$ in 1997: Hungary;

- $\quad$ in 1998: Hungary, and Italy,

- in 1999: Bulgaria, Czech Republic, and Italy.

Legislative updates were registered mainly in the first half of 2000-2010. It was the case of one EU founder state (Germany), seven other old member states (except Denmark, and Finland), and 11 CEE member states (except Czech Republic, and Hungary). Changes of family regulations were noticed:

- $\quad$ in 2000: Malta;

- $\quad$ in 2001: Austria, Croatia;

- $\quad$ in 2002: Bulgaria, Cyprus, Estonia, United Kingdom;

- $\quad$ in 2003: Bulgaria, Croatia, Cyprus, Poland, Portugal, Slovakia;

- $\quad$ in 2004: Bulgaria, Croatia, Estonia, Greece, Lithuania, Romania;

- $\quad$ in 2005: Ireland, Slovakia, Slovenia, Spain;

- $\quad$ in 2006: Portugal, Slovenia;

- $\quad$ in 2007: Cyprus, Estonia, Germany;

- $\quad$ in 2008: Slovakia, Sweden;

- $\quad$ in 2009: Bulgaria, Germany, Latvia, Slovakia.

Changes on family benefits were constantly registered after 2010 in all three types of member states. A singular case is noticed in for one EU founder (Italy), a moderate change for four other old member states (Denmark, Greece, Portugal, and Sweden), and changes in almost half of the latest member states:

- $\quad$ in 2010: Cyprus, Portugal, Romania, Slovenia, Sweden;

- $\quad$ in 2011: Bulgaria, Cyprus, Denmark;

- $\quad$ in 2012: Croatia, Cyprus, Denmark, Italy, Slovenia;

- $\quad$ in 2013: Bulgaria, Germany, Greece, Italy, Slovakia;

- $\quad$ in 2014: Bulgaria.

Family benefits changed with almost the same intensity in both other old member states than the EU founder states, and in Central and East- European new member states. The most frequent changes per category of analysed countries were registered in Italy (as founder state of the EU), in Portugal (as other old member states), and in Bulgaria (among new member states). Early national regulations with impact on family policies had a rather general approach by adopting the Social Security Codes (France, Luxembourg); and Child Benefit Acts (a Federal one in Germany, and a General one in The Netherlands). More specific visions were reflected by adopting the Law on child benefits for employed persons (Belgium 1939) and the Decree of the President of the Republic no. 797 (Italy 1955).

\section{Family benefits and becoming a member state of the European Union}

In terms of distance between the latest update of the family benefits regulation, in comparison with the moment of becoming a EU member state, Belgium is one of the most „conservative" countries. Its current legislative framework with impact on family dates from 1976. At the opposite end, France (2014), Germany and Italy (2013) continue to adjust their national frameworks. One should take into account the fact that on one hand, the assessment of the effectiveness of family policies is not the main concern of this paper, and on the other hand, regular updates of family benefits amounts adopted all over EU are not regarded as changes in the hard legislation. A particular situation is represented by France where the data regarding the adoption of the Social Security Code is not available within the MISSOC 
database. However, one of the reasons could be the yearly and even monthly implementation support for budgetary allocations as the case may be. One of our recommendations would be that the MISSOC database should harmonise and collect complementary/supplementary information on the available national financial tools both in terms of regular amounts and with respect to the financial implementation mechanisms, so as to obtain a more complete and defining image with respect to all countries considered.

Table 1. Recent regulations of family benefits within founder members of the European Union

\begin{tabular}{llcc} 
No. & Country & EU & Latest regulations \\
\hline 1. & France & 1951 & 2014 \\
2. & Germany & 1951 & 2013 \\
3. & Italy & 1951 & 2013 \\
4. & The Netherlands & 1951 & 2004 \\
5. & Belgium & 1951 & 1976 \\
6. & Luxembourg & 1951 & 2008 \\
\hline
\end{tabular}

Source: MISSOC data base http://ec.europa.eu/enlargement/policy/from-6-to-28-members/index_en.htm

Among other old member states except founder members of the EU, the most "conservative" one is Finland where the current regulations regarding family benefits were enforced three years before the EU accession of the country. The latest developments were registered in Demark and Greece in 2013. Eight out of nine old member states continue to change their family regulations after they joined the EU: 40 years after in the case of Denmark; 32 years after in the case of both Ireland and Greece; 29 years after in United Kingdom; 24 years after in Portugal; 15 years after in Sweden; and six years after in Austria. Further research on explaining the period of time required per country should take into account strategic elements related to the development of the social goals agreed at the EU level.

Table 2. Regulations of family benefits within other old member states except the founder states of the European Union

\begin{tabular}{llccc}
\hline No. & Country & Latest regulations & EU accession & Latest regulations \\
\hline 1. & Denmark & - & 1973 & 2013 \\
2. & Ireland & - & 1973 & 2005 \\
3. & United Kingdom & - & 1973 & 2002 \\
4. & Greece & - & 1981 & 2013 \\
5. & Portugal & - & 1986 & 2010 \\
6. & Spain & - & 1986 & 2005 \\
7. & Austria & - & 1995 & 2001 \\
8. & Finland & 1992 & 1995 & - \\
9. & Sweden & - & 1995 & 2010 \\
\hline
\end{tabular}

From the CEE member states, the most "conservative" one is Lithuania which continues to function following regulations adopted ten years before accession. At the opposite end, Bulgaria last adopted modifications in 2014. Five new EU member states maintained their family related regulations as adopted before the year of the EU accession: Lithuania (ten years before), Hungary (six years), Czech Republic (five years), Malta (four years), and Poland (one year). Seven states continued their updates/adjustments of national regulations after EU accession: Estonia and Romania (three years after), Latvia (five years), Bulgaria (seven years); Cyprus and Slovenia (eight years), and Slovakia (nine years). 
Table 3. Regulations of family benefits within Central and Eastern member states

\begin{tabular}{llccc}
\hline No. & Country & Latest regulations & EU accession & Latest regulations \\
\hline 1. & Cyprus & - & 2004 & 2012 \\
2. & Czech Republic & 1999 & 2004 & - \\
3. & Estonia & - & 2004 & 2007 \\
4. & Hungary & 1998 & 2004 & - \\
5. & Latvia & - & 2004 & 2009 \\
6. & Lithuania & 1994 & 2004 & - \\
7. & Malta & 2000 & 2004 & - \\
8. & Poland & 2003 & 2004 & - \\
9. & Slovakia & - & 2004 & 2013 \\
10. & Slovenia & - & 2004 & 2012 \\
11. & Bulgaria & - & 2007 & 2014 \\
12. & Romania & - & 2007 & 2010 \\
13. & Croatia & 2004 & 2013 & - \\
\hline
\end{tabular}

Source: MISSOC data basehttp://ec.europa.eu/enlargement/policy/from-6-to-28-members/index_en.htm

\section{National regulations for family benefits}

Five categories were identified: acts, laws, decrees, codes and other acts. Laws are the most frequent in EU founders, acts in other old member states and equal acts and laws in CEE member states.

Table 4. Regulations of family benefits in EU-28

\begin{tabular}{|c|c|c|c|}
\hline & $\begin{array}{l}\text { Founder members of the } \\
\text { EU }\end{array}$ & Other old member states & $\begin{array}{l}\text { Central and Eastern } \\
\text { member states }\end{array}$ \\
\hline Acts & $\begin{array}{l}\text { Germany, } \\
\text { The Netherlands }\end{array}$ & $\begin{array}{l}\text { Austria, Denmark, Finland, } \\
\text { Ireland, Spain, Sweden, } \\
\text { United Kingdom }\end{array}$ & $\begin{array}{l}\text { Bulgaria, Croatia, Czech } \\
\text { Republic, Estonia, } \\
\text { Hungary, Malta, Slovenia }\end{array}$ \\
\hline Laws & Belgium, Germany, Italy & Greece, Portugal & $\begin{array}{c}\text { Bulgaria, Cyprus, Latvia, } \\
\text { Lithuania, Poland, } \\
\text { Romania, Slovakia }\end{array}$ \\
\hline Decrees & Belgium, Italy & Greece, Portugal, Spain & Bulgaria \\
\hline Codes & France, Luxembourg & Sweden & Bulgaria \\
\hline Other & - & - & Malta, Romania \\
\hline
\end{tabular}

Source: MISSOC data base

The most frequently used piece of regulation is the act. They are mostly dedicated to children (Austria, Croatia, Czech Republic, Denmark, Finland, Germany, Hungary, Sweden, The Netherlands, and United Kingdom), and family (Austria, Bulgaria, Croatia, Denmark, Estonia, Hungary, and Slovenia). Other acts are focused on:

- $\quad$ taxation acts (Croatia, Hungary, Slovenia, and United Kingdom),

- $\quad$ parental acts (Estonia, Germany, Slovenia),

- maintenance benefit acts (Estonia, Germany, Slovenia),

- $\quad$ social welfare acts (Croatia, and Ireland),

- $\quad$ social security acts (Malta, and Spain).

Subjected to the other national acts are: state social support (Czech Republic), labour (Croatia), homeland war veterans and members of their families (Croatia), social services (Denmark), day care (Denmark), benefits of compulsory health insurance (Hungary), exercise of rights to public funds (Slovenia), kindergarten (Slovenia), and child-related allowance (The Netherlands). Laws are mainly focus on:

- $\quad$ children (Belgium, Cyprus, Lithuania, Romania, and Slovakia),

- $\quad$ allowances (Belgium, Italy, Latvia, Romania, and Slovakia),

- family (Italy, Poland, and Slovakia),

- $\quad$ state social insurance (Bulgaria, and Latvia), 
- taxation issues (Germany, and Slovakia).

Other laws refer to: self-employed (Belgium), paternity (Italy), integration of people with disabilities (Bulgaria), the indexing reference of social support (Portugal), maternity and sickness insurance (Latvia), and alternative alimony (Slovakia). Decrees (Bulgaria, Italy, and Portugal), presidential decrees (Greece), and royal decrees (Belgium, Spain) are in force. Five codes are applicable: social insurance code (Bulgaria, Sweden), social security code (France, Luxembourg), and family code (Bulgaria). Other types of national legislation identified in analysed countries are: emergency ordinance (Romania) and regulation (Malta).

\section{Topics of regulation for family benefits}

First five top topics of family regulations identified in EU member states are: child (15 countries), family (13 countries), allowances / benefits (12 countries), taxation (seven countries), and paternity (six countries). Six member states are missing from this common picture: two EU founder states (France, and Luxembourg); three other old member states (Ireland, Greece, and Spain); and one new member state (Malta).

Table 5. Overview of subjects of family benefits within member states of the European Union

\begin{tabular}{|c|c|c|c|c|c|c|}
\hline No. & Country & Child & Family & $\begin{array}{l}\text { Allowance } \\
\text { / benefit }\end{array}$ & Taxation & Paternity \\
\hline 1. & Austria & $\mathrm{x}$ & $\mathrm{x}$ & - & - & - \\
\hline 2. & Belgium & - & $\mathrm{x}$ & - & - & $\mathrm{x}$ \\
\hline 3. & Bulgaria & $\mathrm{x}$ & $\mathrm{x}$ & $\mathrm{x}$ & $\mathrm{x}$ & - \\
\hline 4. & Croatia & $\mathrm{x}$ & $\mathrm{x}$ & $\mathrm{x}$ & $\mathrm{x}$ & - \\
\hline 5. & Cyprus & $\mathrm{x}$ & - & $\mathrm{x}$ & - & - \\
\hline 6. & Czech Republic & $\mathrm{x}$ & - & - & - & - \\
\hline 7. & Denmark & $\mathrm{x}$ & $\mathrm{x}$ & - & - & - \\
\hline 8. & Estonia & - & $\mathrm{x}$ & $\mathrm{x}$ & - & - \\
\hline 9. & Finland & $\mathrm{x}$ & - & - & - & - \\
\hline 10. & Germany & $\mathrm{x}$ & - & - & $\mathrm{x}$ & - \\
\hline 11. & Hungary & $\mathrm{x}$ & $\mathrm{x}$ & $\mathrm{x}$ & $\mathrm{x}$ & $\mathrm{x}$ \\
\hline 12. & Italy & - & $\mathrm{x}$ & - & - & - \\
\hline 13. & Latvia & - & - & $\mathrm{x}$ & - & $\mathrm{x}$ \\
\hline 14. & Lithuania & $\mathrm{x}$ & - & $\mathrm{x}$ & - & - \\
\hline 15. & Poland & - & $\mathrm{x}$ & $\mathrm{x}$ & - & - \\
\hline 16. & Portugal & - & $\mathrm{x}$ & - & - & - \\
\hline 17. & Romania & $\mathrm{x}$ & $\mathrm{x}$ & $\mathrm{x}$ & - & $\mathrm{x}$ \\
\hline 18. & Slovakia & $\mathrm{x}$ & $\mathrm{x}$ & $\mathrm{x}$ & $\mathrm{x}$ & $\mathrm{x}$ \\
\hline 19. & Slovenia & - & $\mathrm{x}$ & $\mathrm{x}$ & $\mathrm{x}$ & $\mathrm{x}$ \\
\hline 20. & Sweden & $\mathrm{x}$ & - & - & - & - \\
\hline 21. & The Netherlands & $\mathrm{x}$ & - & $\mathrm{x}$ & - & - \\
\hline 22. & United Kingdom & $\mathrm{x}$ & - & - & $\mathrm{x}$ & - \\
\hline
\end{tabular}

Source: MISSOC data base

When looking at all member states, social security is subject of family related regulations in four countries: France, Luxembourg, Spain, and Malta. Other subjects are: social services (Denmark, Slovakia, and Slovenia); social support (Portugal, Czech Republic, and Slovenia); and social protection (Czech Republic, Hungary, and Romania). Subjects approached in pairs by member states are noticed in the case of employment (Belgium, and Croatia); welfare (Ireland, and Croatia); social insurance (Sweden, and Bulgaria); and health insurance / sickness (Hungary, and Latvia). There are seven cases of unique use of other topics when referring to family related regulations: European Union obligations (Italy); self-employed (Belgium); gender equality bonus (Sweden); alternative alimony (Slovakia); rights to public funds (Slovenia); people with disabilities (Bulgaria); and homeland war veterans and members of their families (Croatia). 
At frequent topics per category of analysed EU member states, child family and taxation are commonly used by all three categories of countries. Except France and Luxembourg, the four EU founders are equally distributed among identified topics. The subjects of allowance / benefit, and paternity are not identified in other old member states than the EU founders. Save for Malta, all CEE member states are using some of the five topics within national regulations. By frequency, the picture is as follows: Hungary and Slovakia (all topics); Slovenia, Bulgaria, Romania, and Croatia (four topics from which family and allowance / benefit are common); and Cyprus, Lithuania, Estonia, and Poland (two topics, allowance / benefit is common).

Table 6. Main subjects for family benefits by category of member states of the European Union (by the order of their accession to the EU)

\begin{tabular}{|c|c|c|c|c|}
\hline No. & & EU founder states & $\begin{array}{l}\text { Other old member } \\
\text { states }\end{array}$ & CEE member states \\
\hline 1. & Child & $\begin{array}{l}\text { Germany, } \\
\text { The Netherlands }\end{array}$ & $\begin{array}{l}\text { Denmark, United } \\
\text { Kingdom, Austria, } \\
\text { Finland, Sweden }\end{array}$ & $\begin{array}{c}\text { Cyprus, Czech Republic, Hungary, } \\
\text { Lithuania, Slovakia, Bulgaria, } \\
\text { Romania, Croatia }\end{array}$ \\
\hline 2. & Family & Italy, Belgium & $\begin{array}{c}\text { Denmark, Portugal, } \\
\text { Austria }\end{array}$ & $\begin{array}{c}\text { Estonia, Hungary, Poland, Slovakia, } \\
\text { Slovenia, Bulgaria, Romania, } \\
\text { Croatia }\end{array}$ \\
\hline 3. & $\begin{array}{l}\text { Allowance / } \\
\text { benefit }\end{array}$ & The Netherlands & - & $\begin{array}{c}\text { Cyprus, Estonia, Hungary, Latvia, } \\
\text { Lithuania, Poland, Slovakia, } \\
\text { Slovenia, Bulgaria, Romania, } \\
\text { Croatia }\end{array}$ \\
\hline 4. & Taxation & Germany & United Kingdom & $\begin{array}{c}\text { Hungary, Slovakia, Slovenia, } \\
\text { Bulgaria, Croatia }\end{array}$ \\
\hline 5. & Paternity & Italy, Belgium & - & $\begin{array}{l}\text { Hungary, Latvia, Romania, } \\
\text { Slovakia, Slovenia }\end{array}$ \\
\hline
\end{tabular}

Source: MISSOC data base

No common topic related to family issues was identified in all six of them. Still, family and paternity are supported in both Italy and Belgium; child support in Germany and The Netherlands; and social security in France and Luxembourg. As partially mentioned above, other singular subjects identified in family related regulations are: European Union obligations (Italy); taxation (Germany); employment (Belgium), and self-employment (Belgium).

Table 7. Main subjects for family benefits within founder member states of the European Union

\begin{tabular}{llcccc} 
& Country & Family & Child & Social security & Paternity \\
\hline 1. & France & - & - & $\mathrm{x}$ & - \\
2. & Germany & - & $\mathrm{x}$ & - & - \\
3. & Italy & $\mathrm{x}$ & - & - & $\mathrm{x}$ \\
4. & The Netherlands & - & $\mathrm{x}$ & - & - \\
5. & Belgium & $\mathrm{x}$ & - & - & $\mathrm{x}$ \\
6. & Luxembourg & - & - & $\mathrm{x}$ & - \\
\hline
\end{tabular}

Source: MISSOC database

In the case of other old member states except the EU founders, child is the main focus of family regulations followed by family. As partially mentioned above, other singular topics are: social services (Denmark), welfare (Ireland), taxation (United Kingdom), social security (Spain), and gender equality bonus (Sweden). 
Table 8. Main subjects for family benefits within other old member states than the founder members of the European Union

\begin{tabular}{llllc}
\hline No. & Country & Child & Family \\
\cline { 2 - 4 } 1. & Denmark & $\mathrm{x}$ & $\mathrm{x}$ \\
2. & United Kingdom & $\mathrm{x}$ & - \\
3. & Portugal & - & $\mathrm{x}$ \\
4. & Austria & $\mathrm{x}$ & $\mathrm{x}$ \\
5. & Finland & $\mathrm{x}$ & - \\
6. & Sweden & $\mathrm{x}$ & - \\
\hline
\end{tabular}

Source: MISSOC data base

In CEE member states allowance / benefit is the most frequent subject in family related regulations. Next positions are occupied by: child and family (each in eight countries), paternity (six countries), and taxation (five countries).

Table 9. Main subjects for family benefits within Central and Eastern member states

\begin{tabular}{llccccc}
\hline No. & Country & $\begin{array}{c}\text { Allowance } \\
\text { benefit }\end{array}$ & Child & Family & Paternity & Taxation \\
\hline 1. & Cyprus & $\mathrm{x}$ & $\mathrm{x}$ & - & - & - \\
2. & Czech Republic & - & $\mathrm{x}$ & - & - & - \\
3. & Estonia & $\mathrm{x}$ & - & $\mathrm{x}$ & - & - \\
4. & Hungary & $\mathrm{x}$ & $\mathrm{x}$ & $\mathrm{x}$ & $\mathrm{x}$ & $\mathrm{x}$ \\
5. & Latvia & $\mathrm{x}$ & - & - & $\mathrm{x}$ & - \\
6. & Lithuania & $\mathrm{x}$ & $\mathrm{x}$ & - & - & - \\
7. & Malta & - & - & - & - & - \\
8. & Poland & $\mathrm{x}$ & - & $\mathrm{x}$ & - & - \\
9. & Slovakia & $\mathrm{x}$ & $\mathrm{x}$ & $\mathrm{x}$ & $\mathrm{x}$ & $\mathrm{x}$ \\
10. & Slovenia & $\mathrm{x}$ & - & $\mathrm{x}$ & $\mathrm{x}$ & $\mathrm{x}$ \\
11. & Bulgaria & $\mathrm{x}$ & $\mathrm{x}$ & $\mathrm{x}$ & - & $\mathrm{x}$ \\
12. & Romania & $\mathrm{x}$ & $\mathrm{x}$ & $\mathrm{x}$ & $\mathrm{x}$ & - \\
13. & Croatia & $\mathrm{x}$ & $\mathrm{x}$ & $\mathrm{x}$ & $\mathrm{x}$ & $\mathrm{x}$ \\
\hline
\end{tabular}

Source: MISSOC database

As already mentioned, other singular subjects are: social protection (Czech Republic, Hungary, and Romania); social services (Slovakia, and Slovenia); social support (Czech Republic, and Slovenia); and health insurance / sickness (Hungary, and Latvia). In only one country case other registered subjects are: employment (Croatia), social security (Malta); welfare (Croatia); social insurance (Bulgaria); alternative alimony (Slovakia); rights to public funds (Slovenia); people with disabilities (Bulgaria); and homeland war veterans and members of their families (Croatia). We notice that the last two vulnerable groups would require a better attention paid by the state.

\section{Categories of family benefits}

Family benefits provided in EU-28 are classified in four categories including eight different allowances: child-raising allowances, child-benefit, child care allowances, and other benefits (birth and adoption grants, allowance for single parents, special allowances for children with disabilities, advance on maintenance payments and other allowances). The child raising allowances is the most frequent family support being provided in 21 member states. Exceptions are in: one EU founder (The Netherlands), four other old member states (Denmark, Greece, Ireland, and United Kingdom.), and two new member states (Cyprus, and Malta). In nine EU member states, both child-benefit and child care allowances are provided specifically as is the case of two EU founder states (France, and The Netherlands); yet, in the other in spite of the fact that family regulations are focused on child and family support in Germany, Italy, and Belgium (see previous section of the paper) these types of benefits are not 
provided for in a particular manner. The same situation is encountered in three other old member states (Denmark, Finland, and United Kingdom) while in Austria, Portugal, and Sweden family regulations are comparable to the ones of the latter mentioned old founder member-states regarding the focus on child, and family. The two mentioned family allowances are provided in four CEE countries (Hungary, Romania, Slovakia, and Slovenia) even if child and family support are the topic subjected to family regulations in other seven countries (Cyprus, Czech Republic, Estonia, Lithuania, Poland, Bulgaria, and Croatia).

Figure 1. Provision of family benefits in 28 member states of the European Union

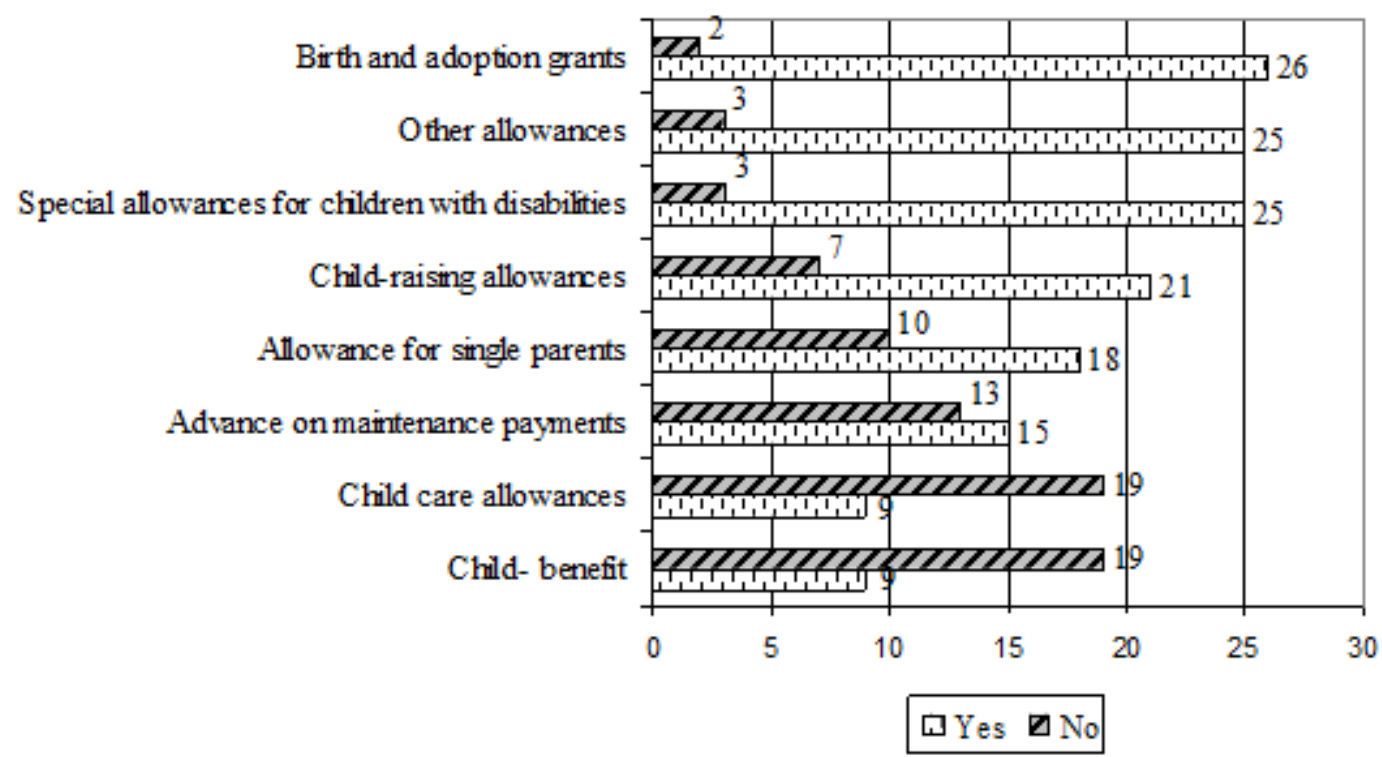

Source: Authors' calculation based on MISSOC data base

When referring to the category of other benefits, top position is occupied by birth and adoption grants provided in 26 member states (except Austria, and Ireland). The next frequent other family benefit is special allowances for children with disabilities which is provided in 25 countries (except Cyprus, Germany, and Italy). Also 25 countries finance other types of allowances (except Cyprus, Spain, and The Netherlands).

The category of other types of allowances includes a variety of forms of financial support: accommodation and housing allowances (Austria, Finland, France, Germany, and Sweden); forms of tax credit especially for dependent children (Austria, Croatia, Hungary, Luxembourg, and United Kingdom); flat-rate allowances (Austria, and Belgium). Family regulations for children are focused on:

- $\quad$ children in day-care centers (Croatia, Czech Republic, Estonia, Lithuania, Malta, and Slovakia);

- $\quad$ orphans / abandoned children (Ireland, Lithuania, and Malta);

- $\quad$ foster care (Latvia, and Lithuania);

- $\quad$ start of school year supplement (France, Luxembourg; and Poland);

- $\quad$ children at school (Bulgaria, and Portugal).

Transport of children is subsidized in Czech Republic, and Slovakia. Transport and accommodation of children at school is financed in Poland (Child Education out of the Place of Residence supplement), and in Slovakia.

Support for parents in different situations is covered in the case of:

- $\quad$ conscript's and alternative civilian (Estonia, and Lithuania);

- $\quad$ parents who stopped working to take care of a child with special needs (Poland, and Spain).

- $\quad$ studying or during an internship and school term (Denmark);

- $\quad$ parental leave (Luxembourg);

- $\quad$ parents back to work earlier after giving birth (Romania). 
Large families with more than three children are financially supported by special regulations (Poland, and Slovenia). Grandparents raising children are entitled to financial support in Germany.

Coming back to the top most frequent eight allowances provided in EU-28, the allowance for single parents is accessible in 18 countries while advance on maintenance payments is regulated in 15 member states. No allowance for single parents is financed in four EU founders (Belgium, Germany, Luxembourg, and The Netherlands), one other old member state (Spain), and five new member states (Bulgaria, Croatia, Czech Republic, Latvia, and Slovakia). Advance on maintenance payments is not regulated in 13 member states: three founder members of the EU (Belgium, Italy, The Netherlands), four other old member states (Greece, Ireland, Portugal, and Spain), and six new member states (Croatia, Cyprus, Czech Republic, Latvia, Lithuania, and Romania).

The eight types of family benefits are fully provided in four countries: one EU founder state (France); one other "old" member state (Finland); and two CEE member states (Hungary, and Slovenia). The smallest number of family allowances is provided in two "old" member states: Ireland (allowance for single parents, and special allowance for children with disabilities), and Spain (child-raising allowances, birth and adoption grants, and special allowance for children with disabilities). In Cyprus as new member state only birth and adoption grants and allowance for single parents are provided. Four founder members of the EU provide four family benefits (Belgium, Germany, Italy, and The Netherlands) and Luxembourg five. Within this category of countries, the most frequent is birth and adoption grants (all six countries); child-raising allowances (five countries except The Netherlands); other allowances (five countries except The Netherlands); special allowance for children with disabilities (four countries except Germany, and Italy). Advance on maintenance payments is provided in France, Germany, and Luxembourg. Child-benefit and child-care allowances are provided in France and The Netherlands. Allowances for single parents are provided in France and Italy.

Table 10. Overview of family benefits in 28 member states of the European Union

\begin{tabular}{|c|c|c|c|c|c|c|c|c|c|}
\hline \multirow[b]{2}{*}{ Country } & \multirow[b]{2}{*}{$\begin{array}{l}\text { Child- } \\
\text { benefit }\end{array}$} & \multirow[b]{2}{*}{$\begin{array}{l}\text { Child- } \\
\text { raising } \\
\text { allow- } \\
\text { ances }\end{array}$} & \multirow[b]{2}{*}{$\begin{array}{l}\text { Child } \\
\text { care } \\
\text { allow- } \\
\text { ances }\end{array}$} & \multicolumn{6}{|c|}{ Other benefits } \\
\hline & & & & $\begin{array}{l}\text { Birth and } \\
\text { adoption } \\
\text { grants }\end{array}$ & $\begin{array}{l}\text { Allow- } \\
\text { ance for } \\
\text { single } \\
\text { parents }\end{array}$ & $\begin{array}{l}\text { Special } \\
\text { allowances } \\
\text { children } \\
\text { disabilities } \\
\end{array}$ & $\begin{array}{r}\text { for } \\
\text { with }\end{array}$ & $\begin{array}{l}\text { Advance } \\
\text { on mainte- } \\
\text { nance } \\
\text { payments }\end{array}$ & $\begin{array}{l}\text { Other } \\
\text { allow- } \\
\text { ances }\end{array}$ \\
\hline Austria & - & $\mathrm{x}$ & - & - & $\mathrm{x}$ & $\mathrm{x}$ & & $\mathrm{x}$ & $\mathrm{x}$ \\
\hline Belgium & - & $\mathrm{x}$ & - & $\mathrm{x}$ & - & $\mathrm{x}$ & & - & $\mathrm{x}$ \\
\hline Bulgaria & - & $\mathrm{x}$ & - & $\mathrm{x}$ & - & $\mathrm{x}$ & & $\mathrm{x}$ & $\mathrm{x}$ \\
\hline Croatia & - & $\mathrm{x}$ & - & $\mathrm{x}$ & - & $\mathrm{x}$ & & - & $\mathrm{x}$ \\
\hline Cyprus & - & - & - & $\mathrm{x}$ & $\mathrm{x}$ & - & & - & - \\
\hline $\begin{array}{l}\text { Czech } \\
\text { Republic }\end{array}$ & - & $\mathrm{x}$ & - & $\mathrm{x}$ & - & $\mathrm{x}$ & & - & $\mathrm{x}$ \\
\hline Denmark & $\mathrm{x}$ & - & $\mathrm{x}$ & $\mathrm{x}$ & $\mathrm{x}$ & $\mathrm{x}$ & & $\mathrm{x}$ & $\mathrm{x}$ \\
\hline Estonia & - & $\mathrm{x}$ & - & $\mathrm{x}$ & $\mathrm{x}$ & $\mathrm{x}$ & & $\mathrm{x}$ & $\mathrm{x}$ \\
\hline Finland & $\mathrm{x}$ & $\mathrm{x}$ & $\mathrm{x}$ & $\mathrm{x}$ & $\mathrm{x}$ & $\mathrm{x}$ & & $\mathrm{x}$ & $\mathrm{x}$ \\
\hline France & $\mathrm{x}$ & $\mathrm{x}$ & $\mathrm{x}$ & $\mathrm{x}$ & $\mathrm{x}$ & $\mathrm{x}$ & & $\mathrm{x}$ & $\mathrm{x}$ \\
\hline Germany & - & $\mathrm{x}$ & - & $\mathrm{x}$ & - & - & & $\mathrm{x}$ & $\mathrm{x}$ \\
\hline Greece & - & - & - & $\mathrm{x}$ & $\mathrm{x}$ & $\mathrm{x}$ & & - & $\mathrm{x}$ \\
\hline Hungary & $\mathrm{x}$ & $\mathrm{x}$ & $\mathrm{x}$ & $\mathrm{x}$ & $\mathrm{x}$ & $\mathrm{x}$ & & $\mathrm{x}$ & $\mathrm{x}$ \\
\hline Ireland & - & - & - & - & $\mathrm{x}$ & $\mathrm{x}$ & & - & $\mathrm{x}$ \\
\hline Italy & - & $\mathrm{x}$ & - & $\mathrm{x}$ & $\mathrm{x}$ & - & & - & $\mathrm{x}$ \\
\hline Latvia & - & $\mathrm{x}$ & - & $\mathrm{x}$ & - & $\mathrm{x}$ & & - & $\mathrm{x}$ \\
\hline Lithuania & - & $\mathrm{x}$ & - & $\mathrm{x}$ & $\mathrm{x}$ & $\mathrm{x}$ & & - & $\mathrm{x}$ \\
\hline Luxembourg & - & $\mathrm{x}$ & - & $\mathrm{x}$ & - & $\mathrm{x}$ & & $\mathrm{x}$ & $\mathrm{x}$ \\
\hline Malta & - & - & - & $\mathrm{x}$ & $\mathrm{x}$ & $\mathrm{x}$ & & $\mathrm{x}$ & $\mathrm{x}$ \\
\hline Poland & - & $\mathrm{x}$ & - & $\mathrm{x}$ & $\mathrm{x}$ & $\mathrm{x}$ & & $\mathrm{x}$ & $\mathrm{x}$ \\
\hline Portugal & - & $\mathrm{x}$ & - & $\mathrm{x}$ & $\mathrm{x}$ & $\mathrm{x}$ & & - & $\mathrm{x}$ \\
\hline Romania & $\mathrm{x}$ & $\mathrm{x}$ & $\mathrm{x}$ & $\mathrm{x}$ & $\mathrm{x}$ & $\mathrm{x}$ & & - & $\mathrm{x}$ \\
\hline Slovakia & $\mathrm{x}$ & $\mathrm{x}$ & $\mathrm{x}$ & $\mathrm{x}$ & - & $\mathrm{x}$ & & $\mathrm{x}$ & $\mathrm{x}$ \\
\hline
\end{tabular}




\begin{tabular}{|c|c|c|c|c|c|c|c|c|c|}
\hline \multirow[b]{2}{*}{ Country } & \multirow[b]{2}{*}{$\begin{array}{l}\text { Child- } \\
\text { benefit }\end{array}$} & \multirow[b]{2}{*}{$\begin{array}{l}\text { Child- } \\
\text { raising } \\
\text { allow- } \\
\text { ances }\end{array}$} & \multirow[b]{2}{*}{$\begin{array}{l}\text { Child } \\
\text { care } \\
\text { allow- } \\
\text { ances }\end{array}$} & \multicolumn{6}{|c|}{ Other benefits } \\
\hline & & & & $\begin{array}{l}\text { Birth and } \\
\text { adoption } \\
\text { grants }\end{array}$ & $\begin{array}{l}\text { Allow- } \\
\text { ance for } \\
\text { single } \\
\text { parents }\end{array}$ & $\begin{array}{l}\text { Special } \\
\text { allowances } \\
\text { children } \\
\text { disabilities }\end{array}$ & $\begin{array}{r}\text { for } \\
\text { with }\end{array}$ & $\begin{array}{l}\text { Advance } \\
\text { on mainte- } \\
\text { nance } \\
\text { payments }\end{array}$ & $\begin{array}{l}\text { Other } \\
\text { allow- } \\
\text { ances }\end{array}$ \\
\hline Slovenia & $\mathrm{x}$ & $\mathrm{x}$ & $\mathrm{x}$ & $\mathrm{x}$ & $\mathrm{x}$ & $\mathrm{x}$ & & $\mathrm{x}$ & $\mathrm{x}$ \\
\hline Spain & - & $\mathrm{x}$ & - & $\mathrm{x}$ & - & $\mathrm{x}$ & & - & - \\
\hline Sweden & - & $\mathrm{x}$ & - & $\mathrm{x}$ & $\mathrm{x}$ & $\mathrm{x}$ & & $\mathrm{x}$ & $\mathrm{x}$ \\
\hline $\begin{array}{l}\text { The } \\
\text { Netherlands }\end{array}$ & $\mathrm{x}$ & - & $\mathrm{x}$ & $\mathrm{x}$ & - & $x$ & & - & - \\
\hline $\begin{array}{l}\text { United } \\
\text { Kingdom }\end{array}$ & $\mathrm{x}$ & - & $\mathrm{x}$ & $\mathrm{x}$ & $\mathrm{x}$ & $\mathrm{x}$ & & $\mathrm{x}$ & $\mathrm{x}$ \\
\hline
\end{tabular}

Source: MISSOC data base

As other old member states, Denmark, and the United Kingdom cover seven family benefits, Sweden six, while Ireland and Spain provide three of them. The most frequent family benefits are: special allowance for children with disabilities (in all nine countries); allowance for single parents, and other allowances (eight countries except Spain); birth and adoption grants (seven countries except Austria and Ireland). Child-raising allowances are provided in five countries (except Denmark, Greece, Ireland, and United Kingdom). Advance on maintenance payments is regulated in five countries (except Greece, Ireland, Portugal, and Spain). Child benefits and child care allowances are provided in Denmark, Finland, and United Kingdom.

Birth and adoption grants are regulated in all 13 CEE member states. The following most frequent family benefits are: special allowance for children with disabilities, and other allowances (each in 12 countries except Cyprus). Child-raising allowance is provided in 11 countries (except Cyprus, and Malta). Allowance for single parents is not regulated in five out of 13 states: in Bulgaria, Croatia, Czech Republic, Latvia, and Slovakia. Advance on maintenance payments is available in seven out of 13 countries: Bulgaria, Estonia, Hungary, Malta, Poland, Slovakia, and Slovenia. Child-benefit and child care allowance are covered in four out of 13 countries: Hungary, Romania, Slovakia, and Slovenia.

\section{Conclusions}

As free movement of workers is a fundamental right guaranteed within the EU member states, and the number of third-country EU migrants continuously increased, the paper intended to tackle a current topic of interest for policy makers and citizens. National regulations with impact on family policies were analysed by three dimensions: time of latest developments in comparison with the year of becoming a member state of the EU, forms of national regulations, and variety of subjects covered by legislative developments. From a historical perspective, earliest regulations on family benefits are from two founder members of the EU (Belgium 1939, and Italy 1955), and from one other "old" member state (Greece 1958). Except 1996, yearly modifications were noticed starting as of 1992 in all three categories of member states. Latest legal modifications in the field of family benefits date from 2013 for both founder members of the EU (Germany, and Italy), and for other "old" member states (Greece), and since 2014 for Bulgaria as representative for the category of new CEE member states. 21 member states continued to update their regulations on family benefits after becoming a member. It is the case of all EU founders, eight other "old" member states (except Finland), and seven out of 13 new CEE member states (except Czech Republic, Hungary, Lithuania, Malta, Poland, and Croatia). Per category of countries, the most "preserved" legislation regarding the family benefits area are from Belgium with latest modifications in 1976 (as EU founder); Finland as of 1992 (as other old member state), and Lithuania as of 1994 (as latest member states).

Four types of national regulations when referring to family benefits were identified in all three categories of countries: acts, laws, decrees, and codes. Other particular forms were only identified in new member states (emergency ordinance in Romania, and regulations in Malta). Acts are the most frequent form of national regulation and they are mainly focused on children 
(ten countries), and on family (seven countries). Laws are focused on children (five countries), and allowances (five countries). Decrees (including presidential and royal ones) are enforced in six countries. Three types of codes are in force in five countries: on social insurance (Bulgaria, and Sweden), on social security (France, and Luxembourg), and family code (Bulgaria).

First three topics of the family benefits regulations are: child (15 countries), family (13 countries), and allowance / benefits (12 countries). Still, child, family and taxation are used in all three types of member states. Allowance / benefit, and paternity are not identified as subjects regarding family benefits regulations in other "old" member states than the EU founder members. National regulations of all Central and Eastern member states (except Malta) are using child, family, allowance / benefit, taxation, and paternity support.

From among the categories of family benefits, birth and adoption grants are provided in 25 member states (except Austria, and Ireland). Special allowances for children with disabilities are provided in 25 countries (except Cyprus, and Germany). Other types of family allowances are provided in 25 countries (except Cyprus, and Spain). Child raising allowance is provided in 21 countries. Allowance for single parents is regulated in 18 countries. Advance on maintenance payments is provided in 15 member states. Both child care allowance and childbenefit are provided within the same nine member states: Denmark, Finland, France, Hungary, Romania, Slovakia, Slovenia, The Netherlands, and United Kingdom. Analysed family benefits are fully provided in four member states: one EU founder state (France); one other old member state (Finland); and two Central and Eastern member states (Hungary, and Slovenia). The smallest number of family allowances is provided in two of the category other old member states: in Ireland and in Spain. In Cyprus as new member state only birth and adoption grants and allowance for single parent are provided. In line with child protection policy ideologically supported during the communist period, all 13 Central and East European countries regulations provide for birth and adoption grants, 12 countries provide special allowance for children with disabilities, and 12 countries provide other allowances.

From the methodological point of view, it should be noticed that using the MISSOC data base we reached the conclusion that a better understanding of family development in the new member states would be supported by including information related to the applicable statutory basis before 1989 in all Central and Eastern member states. Other relevant pieces of information refer to the complete set of comparable data as complementary source of information when used in the case of the years of latest updates in France, and the Netherlands, and the contents of legal changes in the case of Italy, and Greece. Last but not least, differences between updates when referring to the main legislation in the field of family benefits and updates when referring to amounts of family benefits should be further clarified.

The paper originally contributes to the comparative analysis of providing family benefits in the member states of the EU. As future research, the assessment of national strengths and weaknesses in adopting the acquis communautaire could support testing the research hypothesis that among other social policies, the development of family measures was progressively shaped by the national commitment towards achieving the EU goals. Results obtained so far with respect to family benefits' development could be continued by analysing the historical socio-economic and cultural roots of these changes; the effectiveness of covered family benefits, and strategies of building up family resilience strategies.

\section{Acknowledgement}

The work of Simona Maria STĂNESCU is elaborated and published under the auspices of the Institute for the Research of the Quality of Life Romanian Academy, as part of the project co-financed by the European Union by the Sectorial Operational Programme Human Resources Development 2007-2013, within the Project Pluri-and Inter-disciplinarity in Doctoral and Post-Doctoral Programmes Project Code POSDRU/159/1.5/S/141086.

The work of Mirela Ileana NEMTANU is cofinanced from the European Social Fund through Sectoral Operational Programme Human Resources Development 2007-2013, project number POSDRU/159/1.5/S/134197 „Performance and excellence in doctoral and postdoctoral research in Romanian economics science domain". 


\section{References}

Austria (1967). Families' Compensation Act (Familienlastenausgleichsgesetz) of 24 October 1967

Băluță, I. (2014). Child Care in Post-communist Romania between Familialist Ideology, Labour Market and Gender Roles. Revista de Cercetare si Interventie Sociala, 46, 227-242.

Belgium, (1939). Lois coordonnées relatives aux allocations familiales pour travailleurs salariés 19 Decembre 1939.

Blum, S., Rille-Pfeiffer, C. (2010). Major Trends of State Family Policies in Europe. Austrian Institute for Family Studies, University of Vienna

Esping-Andersen, G. (1990). The Three Worlds of Welfare Capitalism. Polity Press, Cambridge.

Esping-Andersen, G., (1999). Social Foundations of Postindustrial Economies. Oxford University Press

European Union's Mutual Information System on Social Protection (MISSOC)

http://www.missoc.org/MISSOC/INFORMATIONBASE/COMPARATIVETABLES/MISSOCDATABASE/co mparativeTableSearch.jsp

European Commission, (2012). An overview of EAF Country Profiles. Employment, Social Affaires \& Inclusion

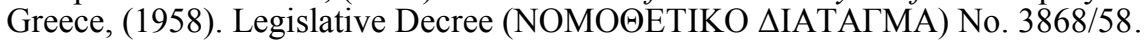

Hirdman, Y., (1994), Women - from possibility to problem? Gender conflict in the welfare state - the Swedish model, The Swedish Centre for Working Life, Stockholm.

Italy, (1955). Decreto del Presidente della Repubblica 30 Maggio 1955, n. 797 - Testo unico delle norme concernenti gli assegni familiari.

Koch, M. (2006). Roads to Post-Fordism Labour Markets and Social Structures in Europe. Editura Ashgate,

Korpi, W. şi Palme, J. (1998). The paradox of redistribution and strategic equality: welfare state institutions, inequality, and poverty in western counties. American Sociological Review, 63, Februarie 1998 în Swedish Social Policy: Literature Compendium, Lund 2000:661 - 687,http://www.lis.ceps.lu/wps/174.pdf accesată 20.04.2000.

Korpi, W. (2000). Faces of Inequality: Gender, Class and Patterns of Inequalities in Different Types of Welfare States. Luxemburg Income Study working paper nr. 224, disponibilă online la: http://www.lis.ceps.lu/wps/224.pdf.

Kvist, J., Saari, J. (editos), (2007). The Europeanisation Of Social Protection. The Policy Press.

Leibfried, S. (1993) Towards a European Welfare State? On Integraion Poverty Regimes into the European Community, în Jones, C. (cordonator) New Perspectives on the Welfare State in Europe. London and New York: Routledge: 133 - 156.

Mureșan, C. (2014). Postponement of Motherhood in Romania: The Role of Educational Attainment. Revista de Cercetare si Interventie Sociala, 47, 137-149.

Pierson, C. (1996). Continuity and discontinuity in the emergence of the post-Fordist welfare state in Burrows, R. şi Loader, B. Towards a post-fordist welfare state, Editura Routledge, ediţia a doua: 95-115

Popescu, R., (2009). Introducere în sociologia familiei Familia romanească în societatea contemporană. Iaşi, Polirom

Stănescu,, S. M.; (2006), Modelul social european, în Zamfir, C.; Stoica, L. (coordonatori), O nouă provocare: dezvoltarea socială. Polirom, Iaşi, 2006

Stănescu, S. M. (2013). Statul bunăstării înte supravieţuire, reformă şi integrare europeană. Bucureşti, ProUniversitaria

Pânzaru, C., Tomiță, M. (2013). Parent Involvement and Early School Leaving. Revista de Cercetare si Interventie Sociala, 40, 21-36

Tomita, M. (2014). Developing Alternative Understandings of Conflicts That Involve Delinquent Children through Life Space Crises Intervention. Revista de Cercetare si Interventie Sociala, 44, 67-85

Turliuc, M., N.; Marici, M., (2013), What do Romanians Parents and Adolescents Have Conflicts about?, Revista De Cercetare Şi Intervenţie Socială, vol. 42/ september 2013, pp. 28-49

Vaughan-Whitehead, D., (2004). EU Enlargement versus Social Europe?, The Uncertain Future of the European Social Model, Edward Elgar Publishing Limited, USA

Vonica Răduţiu, S., (editor), Băjenaru, C., Doboş, C., Niţulescu, D. C., Popescu, R., Stoica, L., (2004). Aderarea României la Uniunea Europeană: impactul asupra statului bunăstării românesc. Academia Română, Institutul Naţional de Cercetări Economice, Biblioteca Economică, colecţia „Probleme economice”, Centrul de Informare şi Documentare Economică, nr. 122-123,

$\mathrm{http}: / /$ www.ilo.org/dyn/natlex/natlex4.detail?p_lang=en\&p_isn=69216

http://www.legifrance.gouv.fr/affichCode.do?cidTexte=LEGITEXT000006073189

http://www.ilo.org/dyn/natlex/natlex4.detail?p_lang=en\&p_isn=69216 